\title{
Sphincterodiplostomum musculosum (Digenea, Diplostomidae) infecting Steindachnerina insculpta (Characiformes, Curimatidae) in the Chavantes Reservoir, Southeastern Brazil
}

Sphincterodiplostomum musculosum (Digenea, Diplostomidae) infectando Steindachnerina insculpta (Characiformes, Curimatidae) no reservatório de Chavantes, Sudeste do Brasil

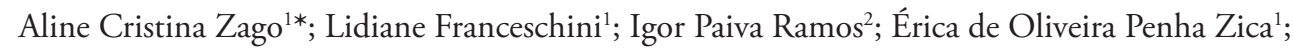
Alison Carlos Wunderlich ${ }^{1}$; Edmir Daniel Carvalho ${ }^{3}$; Reinaldo José da Silva ${ }^{4}$

\begin{abstract}
${ }^{1}$ Programa de Pós-graduação em Ciências Biológicas, Instituto de Biociências, Universidade Estadual Paulista - UNESP, Botucatu, SP, Brasil ${ }^{2}$ Centro de Ciências Biológicas e da Saúde, Colegiado de Ciências Biológicas, Universidade Estadual do Oeste do Paraná - UNIOESTE, Cascavel, PR, Brasil

${ }^{3}$ Departamento de Morfologia, Instituto de Biociências, Universidade Estadual Paulista - UNESP, Botucatu, SP, Brasil

${ }^{4}$ Departamento de Parasitologia, Instituto de Biociências, Universidade Estadual Paulista - UNESP, Botucatu, SP, Brasil
\end{abstract}

Received July 8, 2012

Accepted November 26, 2012

\begin{abstract}
This study aimed to report the infection by Sphincterodiplostomum musculosum metacercariae in Steindachnerina insculpta from the Chavantes Reservoir, medium Paranapanema River, municipality of Ipaussu, State of São Paulo, Brazil. Thirty specimens of S. insculpta were collected and 29 were infected with S. musculosum metacercariae (prevalence $=96.67 \%$ ) in the eyes and visceral cavity. The mean intensity of infection and abundance were 96.6 \pm 29.41 (7-846) and $93.3 \pm 28.6$ (0-846), respectively. Positive correlation was observed between parasite abundance in the eyes and standard length ( $r s=0.5, p=0.005)$, total weight ( $r s=0.649, p=0.0001)$, and condition factor ( $r s=0.439$, $\mathrm{p}=0.0154$ ). The high parasitism rates by $S$. musculosum metacercariae in S. insculpta can be an indicative that this fish species is highly susceptible to infection by this diplostomid, and even reflect the presence of a large abundance of the intermediate host. Moreover, S. musculosum metacercariae are reported for the first time in S. insculpta.
\end{abstract}

Keywords: Diplostomid, metacercaria, Sphincterodiplostomum musculosum, Steindachnerina insculpta, condition factor, Paraná River basin.

\section{Resumo}

O presente estudo tem como objetivo relatar a infecção por metacercárias de Sphincterodiplostomum musculosum em Steindachnerina insculpta provenientes do Reservatório de Chavantes, médio Paranapanema, município de Ipaussu, Estado de São Paulo, Brasil. Foram coletados 30 espécimes de $S$. insculpta, sendo que 29 estavam infectados por metacercárias de $S$. musculosum (prevalência $=96,67 \%$ ) nos olhos e na cavidade visceral. A intensidade média de infecção e abundância apresentaram valores de 96,6 \pm 29,41 (7-846) e 93,3 \pm 28,6 (0-846), respectivamente. Foi observada correlação positiva entre a abundância dos parasitas presentes nos olhos com relação ao comprimento padrão ( $\mathrm{rs}=0.5, \mathrm{p}=0.005)$, peso ( $\mathrm{rs}=0.649, \mathrm{p}=0.0001)$ e fator de condição ( $\mathrm{rs}=0.439, \mathrm{p}=0.0154)$. As altas taxas de parasitismo de metacercárias de $S$. musculosum em $S$. insculpta podem ser um indicativo de que esta espécie de peixe é altamente susceptível à infecção por este diplostomídeo, e até mesmo refletir a presença de grande oferta do hospedeiro intermediário. Além disso, este é o primeiro relato de parasitismo por metacercárias de $S$. musculosum em $S$. insculpta.

Palavras-chave: Diplostomídeo, metacercária, Sphincterodiplostomum musculosum, Steindachnerina insculpta, fator de condição, bacia do rio Paraná.

\footnotetext{
*Corresponding author: Aline Cristina Zago

Instituto de Biociências, Universidade Estadual Paulista - UNESP,

Distrito de Rubião Junior, CEP 18618-970, Botucatu, SP, Brasil

e-mail: alinecristhina@yahoo.com.br
} 


\section{Introduction}

Steindachnerina insculpta Fernández-Yépez, 1948 is a native fish from Brazil and its occurrence is restricted to the Paraná River basin. This fish species belongs to the family Curimatidae and is commonly known in Brazil as saguiru-do-rabo-amarelo (FROESE; PAULY, 2012).

In the aquatic environment, the penetration of pathogens is facilitated and fish can be infected by numerous parasite species (KLEIN et al., 2004). Therefore, a great number of fish species can act as intermediate or definitive hosts of several parasite species (PAVANELLI et al., 2008).

Among fish parasites, the larval stages of digeneans, such as diplostomid metacercariae, are important agents of diseases in these animals, because they can cause severe ocular pathology associated with cataracts and blindness or even death. Diplostomids present a complex three-host life-cycle which involves: a free-living larva (miracidium), which hatches from the egg; two asexual generations (parthenitae) in an aquatic snail; a second free-living larva (cercaria), which is released in huge numbers and is involved in the transmission to the second intermediate fish host, usually penetrating it through the gills; an unencysted larva (metacercaria), usually in the eyes (lens, humour or under the retina) of fishes; and a sexually mature, hermaphroditic adult in the intestine of piscivorous birds (VALTONEN; GIBSON, 1997).
Several species of diplostomids have been found in fish from Asia, Europe, North America, and South America (NIEWIADOMSKA, 1996). In Brazil, metacercariae of the diplostomid Sphincterodiplostomum sp. Dubois, 1936 have been previously reported in some fish species such as Steindachnerina brevipinna Eigenmann and Eigenmann, 1889 (CESCHINI et al., 2010a), Hoplias malabaricus Bloch, 1794, Hemisorubim platyrhynchos Valenciennes, 1840 (TAKEMOTO et al., 2009), Prochilodus lineatus Valenciennes, 1836 (LIZAMA et al., 2006) and Cyphocharax gilbert Quoy and Gaimard, 1824 (ABDALLAH et al., 2005). However, there are no reports on the occurrence of this metacercariae infecting S. insculpta. Thus, the aim of this study is to report the infection by Sphincterodiplostomum musculosum Dubois, 1936 metacercariae in S. insculpta from the Chavantes Reservoir, medium Paranapanema River, municipality of Ipaussu, State of São Paulo, Brazil.

\section{Materials and Methods}

Thirty specimens of S. insculpta were collected in January, 2009 in the Chavantes Reservoir (Figure 1), medium Paranapanema River, municipality of Ipaussu, State of São Paulo, Brazil (23 $7^{\prime} 36^{\prime \prime} S$ and $\left.49.59^{\circ} 23^{\prime} 10^{\prime \prime} \mathrm{W}\right)$. Fish were collected using a nylon monofilament gillnet from 5:00 PM to 7:00 AM, totaling 14 hours of exposure. The fish specimens collected were transported to a laboratory

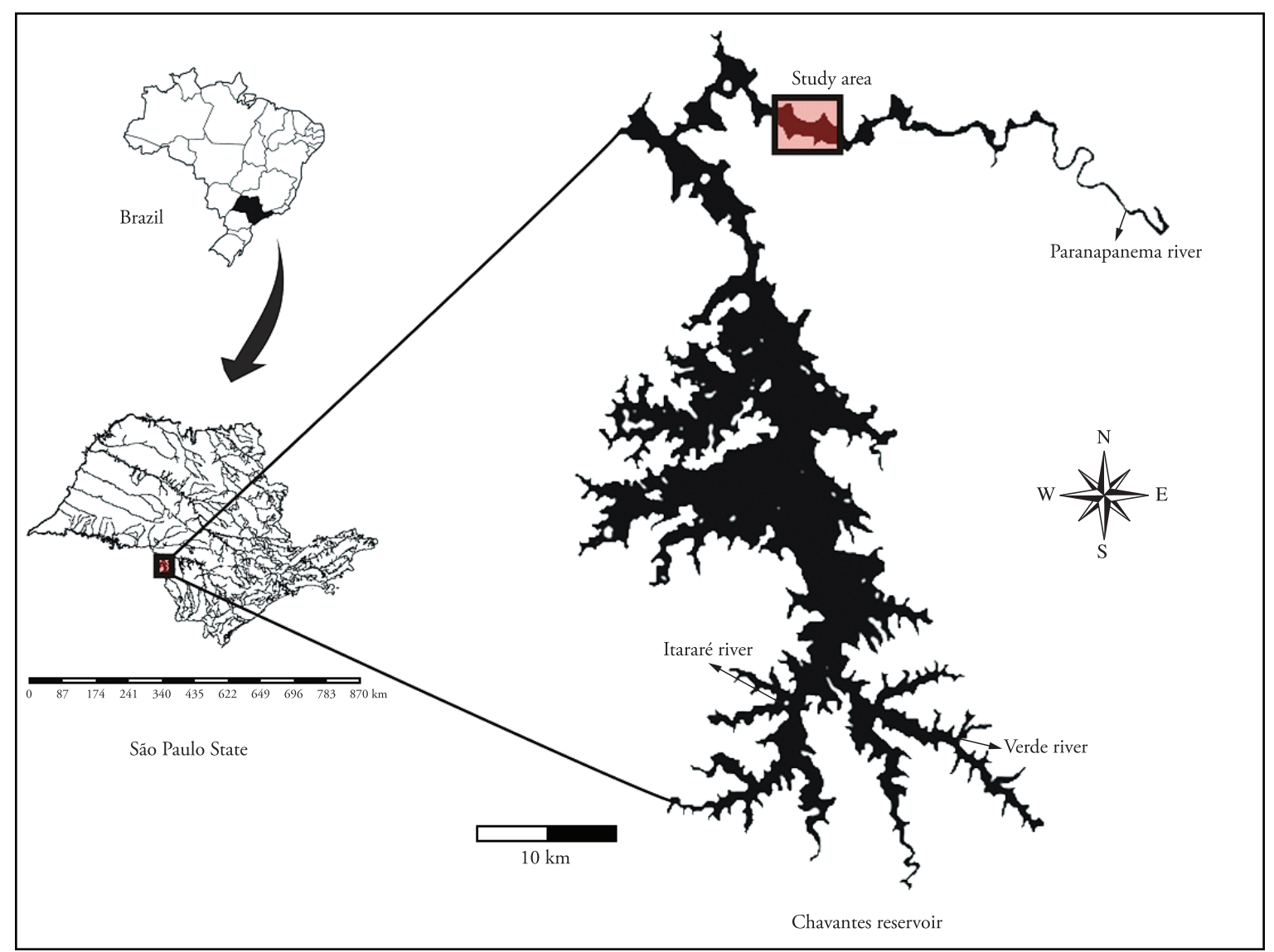

Figure 1. Map of Brazil, highlighting the State of São Paulo and the sampling area at the Chavantes Reservoir, Paranapanema River, municipality of Ipaussu, State of São Paulo, Brazil. 
where they were measured $(\mathrm{cm})$, weighed $(\mathrm{g})$ and necropsied. Organs and body cavities of $S$. insculpta were examined and the metacercariae found were collected, fixed in alcohol-formol-acetic acid solution under cover slip pressure. After that, they were stained with carmine according to Eiras et al. (2006).

Morphometric analysis of the metacercariae was accomplished using a computerized system for image analysis (Qwin Lite 3.1, Leica Microsystems, Wetzlar, Germany). All measurements were presented in micrometers and represented by the mean \pm standard deviation (range). The ecological descriptors of parasitism (prevalence, abundance and mean intensity of infection) were calculated according to Bush et al. (1997). Spearman's rank correlation (rs) was used to study the correlations of the abundance of parasites present in the eyes in relation to standard length, total weight and condition factor - K (LE CREN, 1951). Statistical tests were performed using SigmaStat 3.1 (Systat Software Inc., California, USA), adopting a significance level of $5 \%$.

Voucher specimens were deposited in the Coleção Helmintológica (CHIBB: 6972-6973), of the Departamento de Parasitologia, Instituto de Biociências, Universidade Estadual Paulista - UNESP, municipality of Botucatu, State of São Paulo, Brazil.

\section{Results}

The mean standard length and total weight of the fish analyzed were $12.05(9-16.5) \mathrm{cm}$ and $39.95(13.7-74.3) \mathrm{g}$, respectively.

Twenty-nine $S$. insculpta specimens were infected by S. musculosum metacercariae (prevalence $=96.67 \%$ ). The larvae were found parasitizing the eyes (93.33\%) and visceral cavity (10\%). Two thousand seven hundred ninety-nine metacercariae were collected in the studied specimens, and the mean intensity of infection and abundance were $96.6 \pm 29.41$ (7-846) and $93.3 \pm 28.6(0-846)$, respectively.

A positive correlation was observed between parasite abundance and standard length ( $\mathrm{rs}=0.5, \mathrm{p}=0.005)$ (Figure 2 ), total weight ( $r s=0.649, p=0.0001$ ) (Figure 3 ) and condition factor ( $r s=0.439$, $\mathrm{p}=0.0154$ ) (Figure 4).

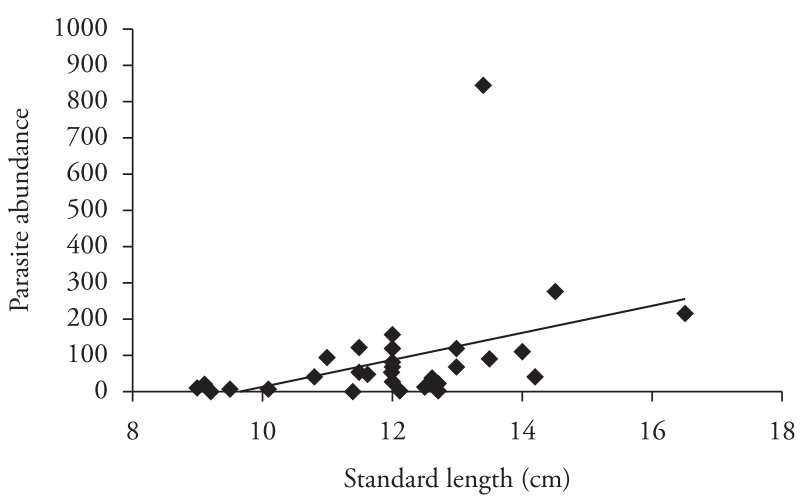

Figure 2. Correlation between standard length and abundance of Sphincterodiplostomum musculosum from the Chavantes Reservoir, medium Paranapanema River, municipality of Ipaussu, State of São Paulo, Brazil.
Description of $S$. musculosum metacercariae (based on 30 specimens) (Figure 5): body bipartite; forebody oval and concave ventrally; hindbody ovoid, much narrower and inserts sub-dorsally in the anterior segment. Forebody with three lobes: the median lobe is occupied by the oral sucker, and the pseudosuckers are located in the lateral lobes; circular tribocitic organ; acetabulum located below of the middle of the forebody; anterior testis asymmetrical and lateral; posterior testis larger than the anterior one, consisting of two elongated lateral masses; anterior ovary adjacent to the anterior testis; sub-terminal sphincter. The morphometric data of S. musculosum metacercariae is summarized in Table 1.

\section{Taxonomic Summary}

Host: Steindachnerina insculpta Fernández-Yépez, 1948.

Site of infection: eyes and visceral cavity.

Locality: Chavantes Reservoir, medium Paranapanema River, municipality of Ipaussu, State of São Paulo, Brazil.

Material: CHIBB (6972-6973)

Mean Intensity of infection: $96.6 \pm 29.41$, up to 846 parasites found in a single host.

Prevalence: $96.67 \%$.

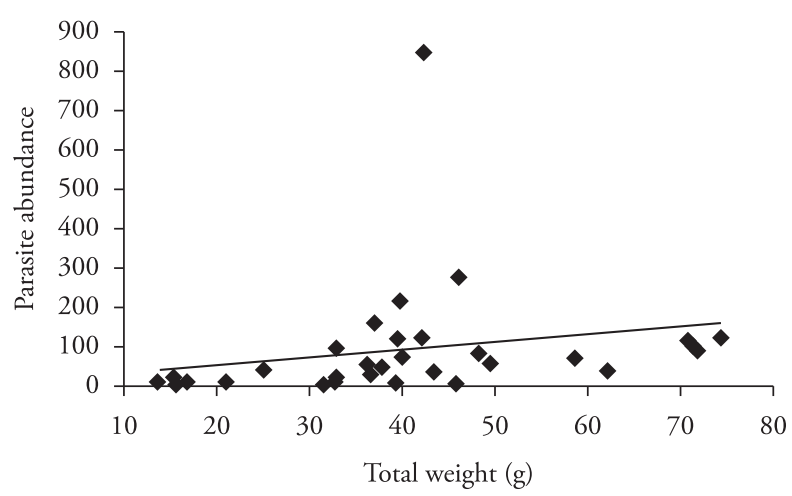

Figure 3. Correlation between total weight and abundance of Sphincterodiplostomum musculosum from the Chavantes Reservoir, medium Paranapanema River, municipality of Ipaussu, State of São Paulo, Brazil.

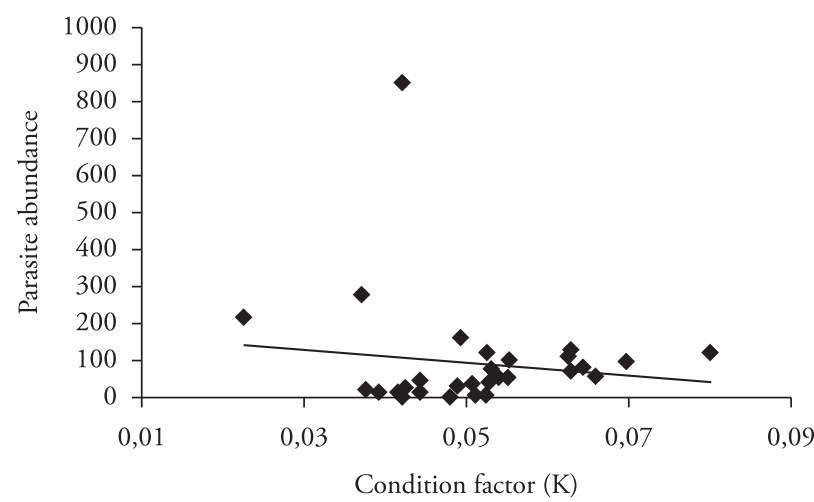

Figure 4. Correlation between condition factor $(\mathrm{K})$ and abundance of Sphincterodiplostomum musculosum from the Chavantes Reservoir, medium Paranapanema River, municipality of Ipaussu, State of São Paulo, Brazil. 
Others hosts: Steindachnerina brevipinna Eigenmann and Eigenmann, 1889 (CESCHINI et al., 2010a), Hoplias malabaricus Bloch, 1794, (TAKEMOTO et al., 2009) and Cyphocharax gilbert Quoy and Gaimard, 1824 (ABDALLAH et al., 2005) to Sphincterodiplostomum musculosum Dubois, 1936 metacercariae; and Hemisorubim platyrhynchos Valenciennes, 1840 (TAKEMOTO et al., 2009) and Prochilodus lineatus Valenciennes, 1836 (LIZAMA et al., 2006) to Sphincterodiplostomum sp. Dubois, 1936 metacercariae.

\section{Discussion}

The present study reports the infection by $S$. musculosum metacercariae in $S$. insculpta from the Chavantes Reservoir, medium Paranapanema River, municipality of Ipaussu, State of São Paulo, Brazil. This parasite species was reported in a few fish species (CESCHINI et al., 2010a; TAKEMOTO et al., 2009; ABDALLAH et al., 2005) in comparison with other diplostomidae,

Table 1. Comparative morphometric data between Sphincterodiplostomum musculosum metacercariae of the Chavantes Reservoir, Paranapanema River, municipality of Ipaussu, State of São Paulo, Brazil, and Steindachnerina brevipinna from the tributaries Guairacá and Corvo of the low Paranapanema River, State of Paraná, Brazil, described by Ceschini et al. (2010a).

\begin{tabular}{|c|c|c|}
\hline \multirow{3}{*}{$\begin{array}{c}\text { Data and measures ( } \mu \mathrm{m}) \text { of } \\
\text { Sphincterodiplostomum musculosum } \\
\text { metacercariae }\end{array}$} & \multicolumn{2}{|c|}{ Host } \\
\hline & Steindachnerina insculpta & Steindachnerina brevipinna ${ }^{b}$ \\
\hline & Mean \pm SD (range) & Mean (range) \\
\hline Locality & $\begin{array}{c}\text { Chavantes Reservoir, medium } \\
\text { Paranapanema River, State of São Paulo, } \\
\text { Brazil }\end{array}$ & $\begin{array}{c}\text { Tributaries Guairacá and Corvo of } \\
\text { the low Paranapanema River, State of } \\
\text { Paraná, Brazil }\end{array}$ \\
\hline Number of metacercariae & 30 & 15 \\
\hline \multicolumn{3}{|l|}{ Body } \\
\hline Length & $2734 \pm 508.8(2151-3982)$ & $2553(1775-3075)$ \\
\hline Width & $1272.4 \pm 231(914.4-1844.3)$ & $1396(1075-1675)$ \\
\hline \multicolumn{3}{|l|}{ Anterior segment } \\
\hline Length & $1642.6 \pm 330.9(1133.9-2346.9)$ & $1530(1150-1900)$ \\
\hline Width & $1272.4 \pm 230.9(914.4-1844.3)$ & $1508(1075-1675)$ \\
\hline \multicolumn{3}{|l|}{ Posterior segment } \\
\hline Length & $1087.4 \pm 259.9(810.9-1811.1)$ & $1033(600-1375)$ \\
\hline Width & $572.8 \pm 79.4(452.8-745.4)$ & $665(500-800)$ \\
\hline \multicolumn{3}{|l|}{ Pharynx } \\
\hline Length & $114.8 \pm 27.5(89.6-218.5)$ & $104(84-117)$ \\
\hline Width & $73.1 \pm 16.1(47.9-113.4)$ & $54(45-84)$ \\
\hline \multicolumn{3}{|l|}{ Oral sucker } \\
\hline Length & $142.4 \pm 34.5(96.3-292.6)$ & $145(100-200)$ \\
\hline Width & $180.5 \pm 31.5(134.8-313.6)$ & $213(130-200)$ \\
\hline \multicolumn{3}{|l|}{ Lateral pseudosucker (1) } \\
\hline Length & $216.4 \pm 57.7(161.5-475.9)$ & - \\
\hline Width & $261.1 \pm 46.2(186.8-438.4)$ & - \\
\hline \multicolumn{3}{|l|}{ Lateral pseudosucker (2) } \\
\hline Length & $217.9 \pm 56.6(1149.8-461.4)$ & - \\
\hline Width & $252.8 \pm 50.4(168.3-454.5)$ & - \\
\hline \multicolumn{3}{|l|}{ Ventral sucker } \\
\hline Length & $142.4 \pm 34.5(96.3-292.6)$ & $162(130-210)$ \\
\hline Width & $180.5 \pm 31.5(134.8-313.6)$ & $213(180-250)$ \\
\hline \multicolumn{3}{|l|}{ Tribocitic organ } \\
\hline Length & $391.5 \pm 85.1(246-644.6)$ & $384(290-440)$ \\
\hline Width & $494.9 \pm 107.2(321.2-732.4)$ & $490(350-650)$ \\
\hline \multicolumn{3}{|l|}{ Anterior testis } \\
\hline Length & $285.4 \pm 62.2(199.8-452.7)$ & $217(130-390)$ \\
\hline Width & $293.2 \pm 49.8(209.4-414.3)$ & $307(250-350)$ \\
\hline \multicolumn{3}{|l|}{ Posterior testis } \\
\hline Length & $310.1 \pm 58.9(210-446.6)$ & $290(210-400)$ \\
\hline Width & $385.1 \pm 79.6(275.2-557.9)$ & $410(200-510)$ \\
\hline
\end{tabular}

aresent study (CHIBB: 6972-6973); ${ }^{\mathrm{b} C e s c h i n i}$ et al. (2010a); Range = min-max; SD = standard deviation (mean). 

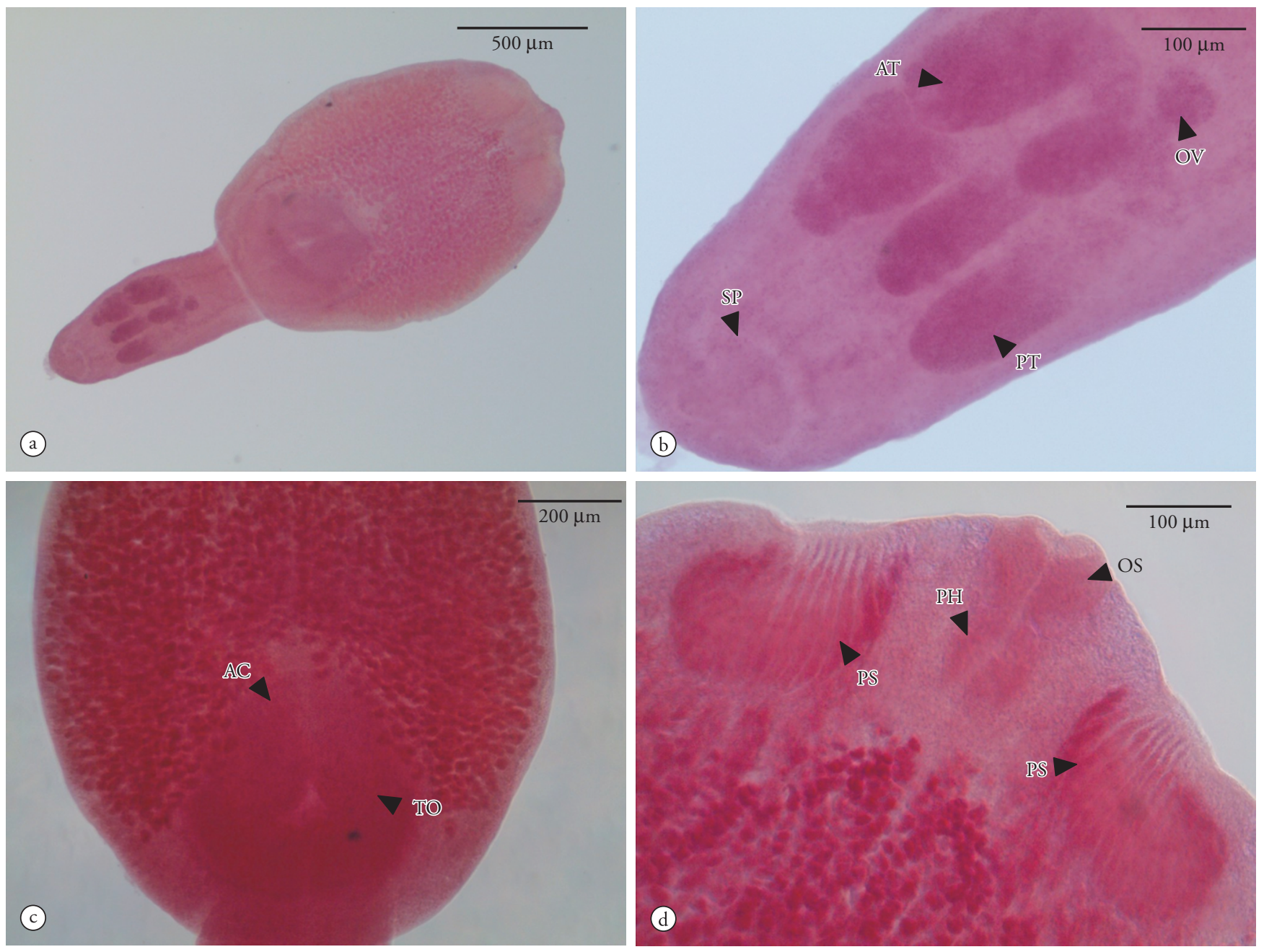

Figure 5. Sphincterodiplostomum musculosum metacercariae found in Steindachnerina insculpta from the Chavantes Reservoir, medium Paranapanema River, municipality of Ipaussu, State of São Paulo, Brazil. a) total body; b) anterior testis (AT), posterior testis (PT), ovary $(\mathrm{OV})$, sphincter (SP); c) acetabulum (AC), tribocitic organ (TO); d) oral sucker (OS), pseudosucker (PS), pharynx (PH).

such as Austrodiplostomum compactum, which was previously reported in approximately 25 fish species (MACHADO et al., 2005; EIRAS et al., 2010; PAES et al., 2010). Furthermore, the studied $S$. insculpta specimens presented high parasitism rates of S. musculosum, indicating that this fish species is high susceptible to infection by this parasite.

The morphological and morphometric data observed in this study to $S$. musculosum metacercariae from $S$. insculpta corroborated the data presented by Ceschini et al. (2010a), who found a high quantity of this diplostomid in the ovaries of S. brevipinna.

The abundance of $S$. musculosum in the eyes of $S$. insculpta was positively correlated to the standard length and total weight. Similar results were found by Ceschini et al. (2010b), who observed positive correlation between the abundance of $S$. musculosum and the standard length of $S$. brevipinna from the tributaries Guairacá and Corvo, in the low Paranapanema River, State of Paraná, Brazil. According to Ceschini et al. (2010b), these results support the idea of cumulative effect of parasites by increasing the area of infection with the growth of the host, as mentioned by Luque et al. (1996), and with the increase of the standard length with the ontogenetic development of the host, the area of the body surface also increases, as well as the possibility of occurring the process of active penetration of cercariae. This pattern was also observed by Paes et al. (2010) and Machado et al. (2005) in relation to other diplostomidae, such as Austrodiplostomum compactum metacercariae.

Positive correlation was also observed between the condition factor $(\mathrm{K})$ and the abundance of $S$. musculosum in the eyes of $S$. insculpta. The condition factor is given by the relationship between the individual's weight and length and it is an important indicator of the fish health, reflecting recent nutritional conditions and the interactions between the fish and the biotic and abiotic factors (LE CREN, 1951; SATAKE et al., 2009). Thus, the results observed in this study suggest that the parasitism by $S$. musculosum could not affect the physiological status, health or welfare of the studied $S$. insculpta specimens.

Sphincterodiplostomum musculosum found in this study were in the larval stage, suggesting that this fish species occupies an intermediate position in the food chain and may be part of the diet of piscivorous birds (definitive hosts of this parasite species). 
In this study, a great number of $S$. musculosum metacercariae was found parasitizing the eyes of $S$. insculpta. According to Evans et al. (1976), around 40 metacercariae of diplostomids per eye may be responsible for cataract or blindness in fish (depending on the size of the host). In our study, no histopathological study was performed to analyze whether the $S$. insculpta specimens were affected by the parasites. However, the fact that the metacercariae were found parasitizing the eyes at high infection rates makes the fish an easier prey for capture by the definitive host (commonly piscivorous birds), so the parasite can complete its life cycle faster (ABDALLAH et al., 2005).

In summary, the high parasitism rates by $S$. musculosum metacercariae in $S$. insculpta can be an indicative that this fish species is highly susceptible to infection by this diplostomid, and even reflect the presence of a large abundance of the intermediate host. Moreover, S. musculosum metacercariae are reported for the first time in S. insculpta.

\section{Acknowledgements}

The authors are grateful to the Fundação de Amparo a Pesquisa do Estado de São Paulo (FAPESP) for the financial support (Process 2007/58246-4 and 2008/58792-1).

\section{References}

Abdallah VD, Azevedo RK, Luque JL. Ecologia da comunidade de metazoários parasitos do sairú Cyphocharax gilbert (Quoy e Gaimard, 1824) (Characiformes: Curimatidae) do rio Guandu, Estado do Rio de Janeiro, Brasil. Rev Bras Parasitol Vet 2005; 14(4): 154-159. PMid:16445872.

Bush AO, Lafferty KD, Lotz JM, Shostak AW. Parasitology meets ecology on its own terms: Margolis et al. revisited. J Parasitol 1997; 83(4): 575-583. PMid:9267395. http://dx.doi.org/10.2307/3284227

Ceschini TL, Takemoto RM, Yamada FH, Moreira LHA, Pavanelli GC. Endoparasites of Steindachinerina brevipinna (Eigenmann and Eigenmann, 1889), collected in the tributaries Corvo and Guairacá of Paranapanema river, State of Paraná, Brazil. Acta Sci Biol Sci 2010a; 32(2): 125-130. http://dx.doi.org/10.4025/actascibiolsci. v32i2.4102

Ceschini TL, Takemoto RM, Yamada FH, Moreira LHA, Pavanelli GC. Metazoan parasite community of Steindachnerina brevipinna (Curimatidae) from Southern Brazil. Helminthologia 2010b; 47(3): 164-169. http:// dx.doi.org/10.2478/s11687-010-0025-8

Eiras CJ, Takemoto MR, Pavanelli GC. Métodos de estudo e técnicas laboratoriais em parasitologia de peixes. 2nd edn. Maringá: EdUEM; 2006.

Eiras CJ, Takemoto MR, Pavanelli GC. Diversidade dos parasitas de peixes de água doce do Brasil. Maringá: Clichetec; 2010.
Evans RS, Heckmann RA, Palmieri J. Diplostomiasis in Utah. Utah Acad Proc 1976; 53(1): 20-25.

Froese R, Pauly D, editors. FishBase [online]. 2012. [cited 2012 June 15]. Available from: http://www.fishbase.org.

Klein S, Feiden A, Boscolo WR, Reidel A, Signor A, Signor AA. Utilização de produtos químicos no controle de Ichthyophthirius multifliis, Fouquet (1876) em alevinos de surubim do Iguaçu Steindachneridion sp., Garavello (1991). Semina: Cienc Agrar 2004; 25(1): 51-58.

Le Cren ED. The length-weight relationship and seasonal cycle in gonad weight and condition in the perch (Perca fluviatilis). J Anim Ecol 1951; 20(2): 201-219. http://dx.doi.org/10.2307/1540

Lizama MAP, Takemoto RM, Pavanelli GC. Parasitism influence on the hepato, splenosomatic and weight/length relation and relative condition factor of Prochilodus lineatus (Valenciennes, 1836) (Prochilodontidae) of the Upper Paraná River Floodplain, Brazil. Rev Bras Parasitol Vet 2006; 15(3): 116-122.

Luque JL, Amato JFR, Takemoto RM. Comparative analysis of the communities of metazoan parasites of Orthopristis ruber and Haemulon steindachneri (Osteichthyes: Haemulidae) from the southeastern Brazilian littoral: I. Structure and influence of the size and sex of hosts. Rev Brasil Biol 1996; 56(2): 279-292.

Machado PM, Takemoto RM, Pavanelli GC. Diplostomum (Austrodiplostomum) compactum (Lutz, 1928) (Platyhelminthes, Digenea) metacercariae in fish from the floodplain of the Upper Paraná River, Brazil. Parasitol Res 2005; 97(6): 436-444. PMid:16151731. http:// dx.doi.org/10.1007/s00436-005-1483-7

Niewiadomska K. The genus Diplostomum - taxonomy, morphology and biology. Acta Parasitol 1996; 41(2): 55-66.

Paes JVK, Carvalho ED, Silva RJ. Infection levels of Austrodiplostomum compactum (Digenea, Diplostomidae) metacercariae in Plagioscion squamosissimus (Teleostei, Sciaenidae) from the Nova Avanhandava reservoir, São Paulo State, Brazil. J Helminthol 2010; 84(3): 284-291. PMid:19889255. http://dx.doi.org/10.1017/S0022149X09990617

Pavanelli GC, Eiras JC, Takemoto RM. Doenças de peixes: profilaxia, diagnóstico e tratamento. 3rd ed. Maringá: EdUEM; 2008.

Satake F, Ishikawa MM, Hisano H, Pádua SB, Tavares-Dias M. Relação peso-comprimento, fator de condição e parâmetros hematológicos de dourado Salminus brasiliensis cultivado em condiçôes experimentais. Dourados: Embrapa Agropecuária Oeste; 2009.

Takemoto RM, Pavanelli GC, Lizama MAP, Lacerda ACF, Yamada FH, Moreira LHA, et al. Diversity of parasites of fish from the Upper Paraná River floodplain, Brazil. Braz J Biol 2009; 69(S2): 691-705. PMid:19738975. http://dx.doi.org/10.1590/S1519-69842009000300023

Valtonen ET, Gibson DI. Aspects of the biology of diplostomid metacercarial (Digenea) populations occurring in fishes in different localities of northern Finland. Ann Zool Fenn 1997; 34(1): 47-59. 